\title{
POTENTIAL HAZARDS OF AN INORGANIC FERTILIZER (WEATFERT) FOR THE BROWN GARDEN SNAIL (EOBANIA VERMICULATA MÜLLER, 1774): GROWTH, HISTOLOGICAL AND BIOCHEMICAL CHANGES AND BIOMARKERS
}

\author{
Attia, L. ${ }^{1}-$ Tine, S. ${ }^{1,2}-$ Tine-DJEBBAR, F. ${ }^{1,2^{*}}-$ Soltani, N. ${ }^{2}$ \\ ${ }^{1}$ Laboratory of Water and Environment, University of Larbi Tébessi, Tébessa, Algeria \\ ${ }^{2}$ Laboratory of Applied Animal Biology, University of Badji Mokhtar, Annaba, Algeria \\ *Corresponding author \\ e-mail: fouzia.djebbar@univ-tebessa.dz; phone: +213-66-355-7273
}

(Received $17^{\text {th }}$ Nov 2020; accepted $16^{\text {th }}$ Feb 2021)

\begin{abstract}
Land snails are often used to monitor soil pollution. The present study aimed to investigate the effects of Weatfert R complex mineral nitrogen, phosphorus, and potassium (N: P: K) fertilizer with high phosphorous content (NPK: 8/36/15 $+\mathrm{SO}_{3}: 13$ ) on Eobania (syn. Helix) vermiculata used as a bioindicator species. Moreover, the histological and biochemical changes in the digestive gland were examined and biomarkers of environmental stress (glutathione peroxidase and lactate dehydrogenase activity) measured. Results showed that the fertilizer tested has a negative impact on the growth rate of juvenile snails. They also revealed alterations in the structure of the digestive gland and changes in biomarker response values in the field, accompanied by significant correlations with bioconcentration. Meanwhile, the biochemical parameters showed varying results representing an increase in the protein rate and a decrease in lipid and carbohydrate rates after treatment with weatfertin. Overall, our study showed that the fertilizer tested could have potential hazards on E. vermiculata and this snail was a suitable sentinel organism and the selected biomarkers are efficient for soil assessment.
\end{abstract}

Keywords: chemical fertilizers, bioindicator organism, growth rate, digestive gland, biochemical changes, biomarkers of oxidative stress

\section{Introduction}

Increasing food production is the main concern of all countries, as world population is expected to grow to nearly 10 billion by 2050 (Gill and Garg, 1998). It has led to the application of a wide variety of chemicals, pesticides and inorganic fertilizers to agricultural land (Yahiaabadi et al., 2018). The usage of inorganic fertilizers has grown in various parts of the world (Lalthanzra and Ramanujam, 2010) and the impact of intensive use is seen not only in terms of the soil quality but also on the survival of soil organisms dwelling there in (Rai et al., 2014). In literature, some researchers have shown that chemical fertilizers are harmful for soil organisms, but on the contrary, others have found that they are beneficial for their food supply (Rai et al., 2014).

Soil is home to different life forms and a reservoir of all the agrochemicals (Yahiaabbadi et al., 2018). To test the effects of chemicals on soil organisms, several biological methods have been applied to nematodes, earthworms, collembolans, and snails (Druart et al., 2011). Mollusca are major part of the world fauna, and the second-largest phylum of the animal kingdom. The terrestrial Gastropoda is one of the most diverse groups of animals, both in shape and habit (Sallam and El-Wakeil, 2012). These animals are of great importance not only due 
to their food value but also for their use in road construction, lime production, preparation of feed for poultry, and finally they indirectly contribute to organic matter decomposition (Bhowmik, 2005).

Several studies have been carried out to determine their activity, especially fertilizers that reach water streams during agricultural activities and may kill snails (Ragab and Showrky, 2006; Ismail, 2009) or make their environmental conditions unsuitable for their life (El-Deeb, 2007). The toxicity endpoints of most of the bioassays are survival, growth, and reproduction (Roh et al., 2010).

Land snails have also been widely used as a sentinel species for the assessment of pollution in terrestrial ecosystems (Douafer et al., 2020). They accumulate various contaminants in their soft tissues, especially the digestive gland, as well as they are helpful species in monitoring the exposure to trace metals, agrochemicals, urban pollution and electromagnetic agents (Regoli et al., 2006). The impact on cellular and biochemical alterations of digestive glands as biomarkers of toxicants have been investigated (Suyman et al., 2006).

Eobania vermiculata (Müller, 1774), the brown garden snail, belongs to the family of Helicidae and is distributed worldwide especially in the Mediterranean area (Radwan et al., 2008). Commonly used as test organism in ecotoxicology studies, it presents several advantages, since it is relatively easy to adapt and maintain in the laboratory conditions, and its physiology is well known (Yousef, 2011).

Terrestrial snails are well known for their capacities to accumulate different classes of chemicals in their tissues, particularly, the hepatopancreas (digestive gland) (Regoli et al., 2006). The possible use of cellular alterations on the gastropods' hepato-pancreas as biomarkers for the exposure to xenobiotics have been investigated (Radwan et al., 2008). The digestive gland is the key organ of chemicals detoxification.

The biochemical responses in organisms exposed to toxic contaminants have been used as biomarkers (Abd-El Azeem and Sheir, 2018). These biomarkers measure the interaction between a biological system and an environmental agent, which might be chemical, physical, or biological (WHO, 1993). In vivo, their inhibition or their induction is a good environmental tool to assess the exposure and the effects of xenobiotics on organisms (Porte et al., 2005).

The use of oxidative stress biomarkers is of potential interest for the assessment of the pollutants impact (Versclar et al., 2008). Moreover, the interaction between xenobiotics and the components of the antioxidant defense systems play an important role in the ecotoxicological response of an organism to its environment (Regoli et al., 2006).

This study was designed to measure the effects during a chronic exposure ( 3 months) of an inorganic fertilizer with high phosphorus content $\left(\right.$ Weatfert $\left.{ }^{\mathrm{R}}\right)$ on survival and growth rates of $E$. vermiculata. The main biochemical components (proteins, carbohydrates and lipids) and the biomarker responses biomarkers were also determined in the digestive gland of the snails. In addition, the histological alterations of the digestive gland due to fertilizer accumulation were examined.

\section{Materials and methods}

\section{Snail's collection and maintenance}

E. vermiculata was collected from untreated area in Bekkaria $\left(35^{\circ} 22^{\prime} 20^{\prime \prime} \mathrm{N} ; 8^{\circ} 14^{\prime}\right.$ 32" E) (Tebessa, Northeast Algeria) in autumn and winter of 2017-2018. The collection 
was always made manually. The collected snails $(1.90 \pm 0.029 \mathrm{~mm}$ in the shell diameter and $3.43 \pm 0.04 \mathrm{~g}$ in body weight $)$ were transferred in glass boxes $(20 \times 20 \times 20 \mathrm{~cm})$ with $5 \mathrm{~cm}$ layer of moistened soil at the bottom. They were identified according to the key of (Godan, 1983). The animals were fed with lettuce leaves and the food was renewed on alternate days. The snails were acclimatized for 2 weeks under laboratory conditions $\left(16 \pm 1{ }^{\circ} \mathrm{C} ; 31 \%\right)$ relative humidity and a $18: 6 \mathrm{~h}$ light-dark cycle before the beginning of experiments (Gomot, 1994).

\section{Chemicals and treatment}

Weatfert (Profert, Bejaia, Algeria) is a trade name of an inorganic fertilizer. It contains a mixture of the three principal nutrients $\left(8 \% \mathrm{~N}+36 \% \quad \mathrm{P}_{2} \mathrm{O}_{5}+15 \% \quad \mathrm{~K}_{2} \mathrm{O}\right)$ $+13 \% \mathrm{SO}_{3}$. Thereafter, 16 snails were added to each box and the sets were subdivided as follows after 14 days of adaptation; three boxes were applied for a control test. Six boxes were treated with two doses of Weatfert, (i) the first treatment with a recommended agricultural dose $\left(D_{1}=500 \mathrm{mg} / 400 \mathrm{~cm}^{2}\right)$ normally used by farmers $(1.5$ quintals per hectare) and (ii) the second treatment with a recommended agricultural dose $\mathrm{x} 2\left(\mathrm{D}_{2}=1000 \mathrm{mg} / 400 \mathrm{~cm}^{2}\right)$. The amount of fertilizer required was determined by the total area of the experimental box $\left(400 \mathrm{~cm}^{2}\right)$. These were added to the soil surface and then mixed thoroughly with enough water to ensure a homogeneous mixture. For the control treatment, distilled water was used. Treatment was done for 3 months. The tested fertilizer was replaced weekly using the same concentration.

\section{Determination of growth inhibition}

Weight growth is assessed weekly by weighing the snails with an analytical balance (Ohaus ${ }^{\circledR}$ Analytical, Switzerland). The inhibition percentage of average weight ( $\left.\mathrm{W}_{\mathrm{ip}}\right)$ (ISO 15952) (Eq. l) is calculated to compare the average weight of the groups treated with that of the control group.

$$
\text { Wip of group } G x=\frac{(W T n-W T 0)-(W G M-W G 0)}{[W T n-W T 0)} \times 100
$$

where:

$\mathrm{W}_{\text {ip }}$ inhibition percentage of average weight

Group $G_{X}$ represents the groups of treated snails $G_{1}, G_{2}$

$\mathrm{W}_{\mathrm{Tn}}$ is the mass of the snails in the control group at time $\mathrm{t}=\mathrm{n}$ weeks

$\mathrm{W}_{\mathrm{T} 0}$ is the mass of control group snails at the start of the experiment

$\mathrm{W}_{\mathrm{Gn}}$ is the mass of snails in the $\mathrm{G}_{\mathrm{X}}$ group at time $\mathrm{t}=\mathrm{n}$ weeks

$\mathrm{W}_{\mathrm{G} 0}$ is the mass of $\mathrm{G}_{\mathrm{X}}$ group snails at the start of experience

\section{Biochemical composition of digestive glands}

Digestive glands from control and treated snails were dissected out at different times $(0,1,2$ and 3 months). The main biochemical components (proteins, carbohydrates and lipids) were extracted following the procedure of Shibko et al. (1966). Fragments $(100 \mathrm{mg})$ of the digestive gland were extracted in $1 \mathrm{~mL}$ of TCA (20\%). In brief, quantification of proteins was carried following the Coomassie Brilliant Blue G-250 dye-binding method of Bradford (1976) with bovine serum albumin as a standard. The absorbance was measured at $595 \mathrm{~nm}$. Carbohydrates were determined as described by Duchateau and Florkin (1959) using anthrone as reagent 
and glucose as standard. Lipids were measured by the vanillin method of Goldsworthy et al. (1972). Data were expressed in $\mu \mathrm{g}$ per mg of fresh tissue and assays conducted with three replicates per treatment each containing $100 \mathrm{mg}$ of digestive gland fragment.

\section{Biomarker assays}

Two doses (500 and $1000 \mathrm{mg} / 400 \mathrm{~cm}^{2}$ ) of Weatfert were orally applied on $E$ vermiculata and its effects examined on LDH and GPx activities measured at various times $(0,1,2$ and 3 months during treatment. GPx activity was determined according to the method of Flohe and Gunzler (1984). Fragments of digestive gland (100-200 mg) were homogenized in $1 \mathrm{ml}$ of phosphate buffer $(\mathrm{pH} \mathrm{7.8).} \mathrm{The}$ homogenate was centrifuged (3000 rpm for $10 \mathrm{~min}$ ) and then the supernatant recovered for use as enzyme source. The assay was performed with $200 \mu \mathrm{l}$ of supernatant added to $400 \mu \mathrm{l}$ of GSH solution $(0.2 \mathrm{mM}, \mathrm{pH} 10)$. Absorbance reading was done after $5 \mathrm{~min}$ at $412 \mathrm{~nm}$. The LDH assay was based on the conversion of lactate to pyruvate or pyruvate to lactate. The lactate dehydrogenase activity (LDH) was spectrophotometrically measured according to the method of Hill and Lévi (1954) as previously described (Sifi and Soltani, 2019). It uses NAD (nicotinamide adenine dinucleotide) as substrate. Fragments of digestive gland (100-200 mg) were homogenized in $1 \mathrm{ml}$ of Tris/ $\mathrm{HCl}(0.1 \mathrm{M}, \mathrm{pH} 7.2)$. The homogenate was centrifuged (3000 rpm for $5 \mathrm{~min}$ ) and then the supernatant recovered for use as enzyme source. The assay was performed with $50 \mu \mathrm{l}$ of supernatant added to $675 \mu \mathrm{l}$ of substrate buffer $(0.2 \mathrm{M}, \mathrm{pH} 10)$ and $50 \mu \mathrm{l}$ of NAD solution. The absorbance reading was done every minute for $5 \mathrm{~min}$ at $340 \mathrm{~nm}$. The protein content was evaluated according to Bradford (1976) using bovine serum albumin as standard (BSA, Sigma). The activity was expressed as $\mu \mathrm{M} / \mathrm{min} / \mathrm{mg}$ protein.

\section{Histological procedure}

The histological procedure was performed according to the method of Gabe (1968). In brief, 16 snails from each control and treated series $\left(\mathrm{D}_{1}\right.$ and $\left.\mathrm{D}_{2}\right)$ were randomly collected (at two periods: 0 day and 3 months) and the digestive glands were dissected. Each whole digestive gland was fixed in formalin solutions $(30 \%)$ for $24 \mathrm{~h}$, and dehydrated in baths of alcohol with increasing concentrations (70, 80, 90 and 95\%). Then, specimens were cleared in xylene and embedded in paraffin wax. Serial sections $(4 \mu \mathrm{m})$ were prepared by a Leitz microtome and stained using the hematoxylin and eosin. Sections were then mounted and covered with glass cover. Histological sections were examined under the light microscope (Leica DM LB2).

\section{Statistics}

Data are presented as a mean value \pm SEM (standard error mean) in each treatment group. The normality of data was verified using the Kolmogorov-Smirnov test, and the homogeneity of variances was checked by Levene's test. Comparison of the experimental groups was tested by analysis of variance (ANOVA), and means were tested for statistical significance by a post hoc Tukey's honestly significant difference test. The statistical tests were performed using GraphPad Prism, version 7.00 (GraphPad Software, San Diego, CA, USA), where $\mathrm{p}<0.05$ indicates a statistically significant difference. 


\section{Results and discussion}

\section{Effects on growth of snails}

The growth of juvenile snails is noted monthly during the treatment period (3 months). The tested fertilizer resulted in an increase of growth inhibition (\%) of snails without dose-response relationship and a decrease during the tested time. The growth of these snails is inhibited after treatment with two doses respectively, and displays percentages ranging from 69 and $78 \%$ for the first month, from 55 to $61 \%$ for the second month and from 49 to $54 \%$ for the third month (Fig. 1).

The use of change in body mass as a biomarker is ecologically relevant, as high body mass losses are believed to have negative effects on survival and reproduction (Dittbrenner, 2010). Treatments with three types of NPK fertilizers (high nitrogen, high phosphorus and balanced) (El-Deeb, 2017) or with urea product (Ragab and Shoukry, 2006) were found to influence snail growth. Meanwhile, Abdel Hamid et al. (1998) reported that urea and ammonium nitrate reduced the growth of juvenile B. alexandrina snails. Schuytema et al. (1994) reported a significant reduction in weight and shell diameter of Helix aspersa snails treated with Aminocarb, Methyl parathion and Paraquat; the responses observed varied according to the type of pesticides and dose administered. Furthermore, the overall results seem to indicate that the reduction in growth is linked to the mode (Sallama et al., 2005; Radwan et al., 2008) and to the duration of treatment exposure (Coeurdassier et al., 1957). Similarly, growth of snails (Helix aspersa) exposed to pesticides (thiamethoxam and tefluthrin) was affected (AitHamlet, 2012). Afomezie et al. (2011) found that NPK soil treatment affects snail's performance by reducing their final weight and weight gain. Bhattacharya and Sahu (2016) showed clearly that the recommended dose of NPK did not cause earthworm mortality.

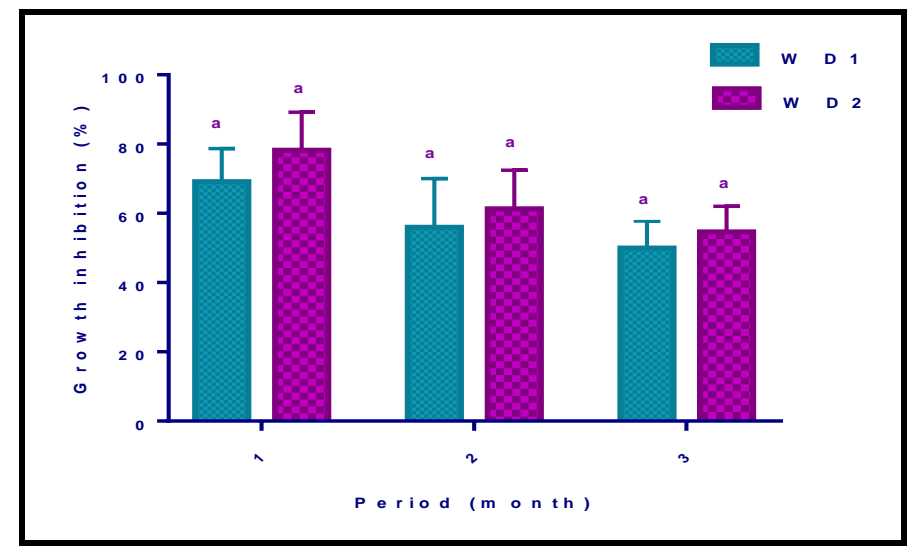

Figure 1. Effects of fertilizer administrated at two doses on growth inhibition (\%) in juvenile snails of E. vermiculata (mean $\pm S E M, n=5$ repeats, each containing 10 individuals): Same lowercase letters indicate no-significant differences at the same time based on T student test $(p>0.05)$

\section{Effect on biochemical composition of digestive glands}

The fertilizer Weatfert was applied to juveniles of $E$. vermiculata during 3 months. Its effects were evaluated on the main biochemical components (carbohydrates, lipids, 
proteins) of digestive glands at different times (0,1, 2 and 3 months) after treatment (Table 1).

Results of the protein amounts showed a significant increase in treated series with the highest dose (dose 2) at the first $(\mathrm{p}=0.007)$ and the third month $(\mathrm{p}=0.008)$ as compared to control series. At the second month, the two applied doses induced a significant increase (control vs dose 1: $p=0.032$; control vs dose $2: p=0.013$ ) of this component, without dose-response relationship.

Table 1. Effects of Weatfert on protein, lipid and carbohydrates rates in digestive gland ( $\mu \mathrm{g} / \mathrm{mg}$ of fresh tissue; $n=3$ pools each containing $100 \mathrm{mg}$ of fresh tissue) at different periods during treatment in the juveniles of E. vermiculata (mean $\pm S E M$ )

\begin{tabular}{c|c|c|c|c}
\hline Components & Times (month) & Control & Dose 1 & Dose 2 \\
\hline \multirow{5}{*}{ Proteins } & 0 & $57.73 \pm 3.27 \mathrm{a}, \mathrm{A}$ & $56.07 \pm 3.27 \mathrm{a}, \mathrm{A}$ & $65.78 \pm 4.19 \mathrm{a}, \mathrm{A}$ \\
& 1 & $59.25 \pm 3.55 \mathrm{a}, \mathrm{A}$ & $72.91 \pm 5.00 \mathrm{a}, \mathrm{B}$ & $88.64 \pm 7.12 \mathrm{~b}, \mathrm{~B}$ \\
& 2 & $69.25 \pm 2.48 \mathrm{a}, \mathrm{A}$ & $87.46 \pm 5.61 \mathrm{~b}, \mathrm{C}$ & $91.57 \pm 5.84 \mathrm{~b}, \mathrm{~B}$ \\
& 3 & $89.96 \pm 11.31 \mathrm{a}, \mathrm{B}$ & $97.25 \pm 8.20 \mathrm{a}, \mathrm{C}$ & $130.66 \pm 1.85 \mathrm{~b}, \mathrm{C}$ \\
\hline \multirow{4}{*}{ Lipids } & 0 & $36.69 \pm 3.31 \mathrm{a}, \mathrm{A}$ & $36.33 \pm 1.17 \mathrm{a}, \mathrm{A}$ & $36.11 \pm 3.16 \mathrm{a}, \mathrm{A}$ \\
& 1 & $38.28 \pm 1.77 \mathrm{a}, \mathrm{A}$ & $27.88 \pm 1.24 \mathrm{~b}, \mathrm{~B}$ & $19.84 \pm 2.46 \mathrm{c}, \mathrm{B}$ \\
& 2 & $39.61 \pm 1.49 \mathrm{a}, \mathrm{A}$ & $27.00 \pm 2.57 \mathrm{~b}, \mathrm{~B}$ & $19.39 \pm 1.32 \mathrm{c}, \mathrm{B}$ \\
& 3 & $57.73 \pm 1.78 \mathrm{a}, \mathrm{B}$ & $18.57 \pm 2.28 \mathrm{~b}, \mathrm{C}$ & $14.65 \pm 0.70 \mathrm{~b}, \mathrm{~B}$ \\
\hline \multirow{3}{*}{ Carbohydrates } & 0 & $61.28 \pm 1.49 \mathrm{a}, \mathrm{A}$ & $63.40 \pm 1.12 \mathrm{a}, \mathrm{A}$ & $63.81 \pm 1.83 \mathrm{a}, \mathrm{A}$ \\
& 1 & $61.74 \pm 1.88 \mathrm{a}, \mathrm{A}$ & $59.31 \pm 2.29 \mathrm{a}, \mathrm{A}$ & $52.61 \pm 3.57 \mathrm{a}, \mathrm{B}$ \\
& 2 & $64.02 \pm 1.79 \mathrm{a}, \mathrm{A}$ & $57.92 \pm 0.89 \mathrm{a}, \mathrm{A}$ & $40.81 \pm 3.41 \mathrm{~b}, \mathrm{C}$ \\
& 3 & $74.28 \pm 0.60 \mathrm{a}, \mathrm{B}$ & $48.94 \pm 4.49 \mathrm{~b}, \mathrm{~B}$ & $22.92 \pm 1.18 \mathrm{c}, \mathrm{D}$ \\
\hline
\end{tabular}

Mean values followed by different lowercase letter indicate significant differences between control and treated series

Mean values followed by different capital letter indicate significant differences between periods based on Tukey's HSD test at $\mathrm{p}<0.05$

Concerning the lipid rate, a significant reduction was observed in the first (control vs dose 1: $p=0.005$; control vs dose 2: $p<0.001$; dose 1 vs dose $2: p=0.0184$ ), the second (control vs dose 1: $\mathrm{p}=0.0019$; control vs dose $2:<0.001$; dose 1 vs dose 2 : $\mathrm{p}=0.0218$ ) and the third month (control vs dose $1: \mathrm{p}<0.001$; control vs dose 2 : $\mathrm{p}<0.001)$ in the treated series with the two tested doses compared to controls.

Finally, our results also revealed a significant decrease in carbohydrates amounts with the highest dose at the first month (control vs dose $2: \mathrm{p}=0.0496$ ), the second (control vs dose 2: $\mathrm{p}=0.0002$; dose 1 vs dose $2: \mathrm{p}=0.001$ ), and the third month (control vs dose 1: $\mathrm{p}=0.0003$; control vs dose $2: \mathrm{p}<0.0001$; dose 1 vs dose 2: $\mathrm{p}=0.0003)$ as compared to control series (Table 1$)$.

Biochemical and enzymatic parameters in organisms exposed to toxic contaminants have been used as biomarkers and may be considered an important diagnostic tool to assess the exposure and effects of xenobiotics (Mclouglin et al., 2008). The increasing demands of organisms to energy during stress to detoxify, bio-transform and excrete the toxicants is achieved by the use of carbohydrate as the principal and immediate energy source (Umminger, 1977). 
Glycogen breakdown and increased glucose are among the well-known mechanisms to provide energy in mollusks in stressful environments (Tunholi et al., 2017). The energy is used to cope with the cytotoxicity induced by pesticides. In our research, the tested fertilizer, weatfert caused a significant reduction in the energy reserves as evidenced by a reduction in carbohydrate rates. In this regard reported a decrease in tissue glycogen levels and an increase in hemolymph glucose concentration in the freshwater snails (Bulinus truncates) exposed to glyphosate herbicide (Bakry et al., 2012). Similarly, the reduction of tissue glycogen has been reported in the mud snails (Amphibola crenata) exposed to waterborne cadmium (De Silva et al., 2018). The results of Mohammadein et al. (2013) and Radwan et al. (2008) disagree with our results, who found a significant decrease in the glycogen content of the digestive gland in land snails treated with heavy metal and chemicals (methomyl and methiocarb), respectively. This may result from an increased rate of glycogen breakdown (glycogenolysis). Moreover the decrease in glycogen content may have an indirect effect on the protein and lipid reserves in E. vermiculata. The results of Banaee and Taheri (2019) indicated significantly lower levels of glycogen and total antioxidant in the cells in the freshwater snail, Galba truncatula exposed to sewage compared to controls.

Proteins are one of the major groups of biological materials comprising the chief nitrogenous elements of the body tissues. The concentration of free amino acids in mollusk varies with pollution levels (Bishop, 1983). Proteins are mainly involved in the architecture of the cell (Radwan et al., 2008). During chronic periods of stress, the snails needed more energy to detoxify the toxicants and to overcome the induced stress (El-Shenawy et al., 2012) especially when they have a limited amount of carbohydrates and lipids (Radwan et al., 2008). Our experiment showed a significant increase in protein ratesin E. vermiculata treated with Weatfert fertilizer. The results of the study of Khalil (2016) suggest that the exposure to sublethal doses of pesticide, methomyllannate may influence total protein metabolism. Previously, Bakry et al. (2011) reported that two pesticides, deltamethrin and malathion had qualitative and quantitative effect on the protein patterns of Helisoma duryi snails. Furthermore, the electrophoretic profil of total proteins from Biomphalaria alexandrina snails treated with diazinon and profenfos showed less number of protein bands, indicating that the pesticides were thought to induce damage in these snails (Bakry et al., 2013). Padmaja and Rao (1994) suggested that the decrease in snail proteins treated with pesticides could be due to several mechanisms namely (a) the formation of lipoproteins which are utilized for the repair of damaged cells and tissue organelles, and (b) the direct utilization by cells for energy requirements (Radwan et al., 2008).

Lipids play extremely important roles in the normal function of a cell. They not only serve as highly reduced storage form of energy, but they also play an intimate role in the structure of cell membranes and the organelles found in the cell (Kandil et al., 2009). Indeed, lipids are the preferred energy fuel offered to tissues when needed after carbohydrates. During periods of chronic stress, they also constitute another source of energy (Moussard, 1999). When snails have a limited amount of carbohydrates and fat, the alternative energy source to meet the increased demand for energy is protein (Moussard, 1999). A decrease in total lipids was noted in E. vermiculata snails treated with Weatfert fertilizer compared to control snails. In addition, these results are similar to those of Aït Hamlet et al. (2012) showed that the Thiamethoxam causes a disturbance in the lipids content in the digestive gland of treated snails compared with controls. 
Moreover, depletion of some long chain and short chain fatty acids may be explained on the basis that reduction in rates of glucose metabolism in the snails was balanced through the stimulation of triglyceride hydrolysis and fatty acid oxidation (Ait-Hamlet et al., 2012).

\section{Effects on biomarkers responses}

Results of the specific activities of antioxidant defense enzyme (GPx and LDH) in $E$. vermiculata exposed to two doses of fertilizer are shown in Figures 2 and 3. The results showed a significant increase in GPx activity at the first $(\mathrm{p}<0.001)$, the second $(\mathrm{p}<0.001)$ and the third month $(\mathrm{p}<0.001)$ respectively as compared to control series, with dose-response relationship at the first (dose 1 vs dose $2: \mathrm{p}=0.016)$ and the third month (dose 1 vs dose 2: $\mathrm{p}=0.006$ ) (Fig. 2).

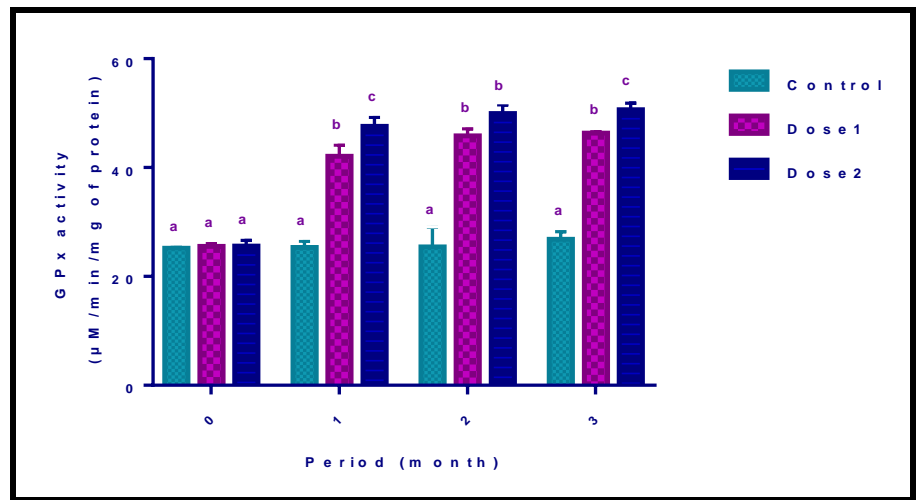

Figure 2. Effect of Weatfert on LDH activities ( $\mu \mathrm{M} / \mathrm{min} / \mathrm{mg}$ of proteins) in the juvenile snails of $E$. vermiculata at different times during treatment (mean $\pm S E M, n=3$ ). The different lowercase letters indicate significant differences at the same time based on Tukey's HSD test $(p<0.05)$

Finally, our results also showed a significant increase in the activity of LDH in the treated series (dose 1 and dose 2) at all tested periods: the first (control vs dose 1: $\mathrm{p}=0.0031$; control vs dose $2: \mathrm{p}<0.001$ ), the second (control vs dose $1: \mathrm{p}=0.0015$; control vs dose $2: \mathrm{p}<0.001)$ and the third month $(\mathrm{p}<0.001)$ as compared to control series respectively (Fig. 3). In addition, we note a significant difference between the two tested doses only at the first month (dose 1 vs dose $2: \mathrm{p}=0.036$ ).

Biomarkers are essential for ecosystem health assessment and management (Boyd, 2010). The study of the antioxidant defense system is increased because of its potential utility to provide biochemical biomarkers that can be used in environmental monitoring systems (Ballesteros, 2009).

Glutathione peroxidase (GPx) known as the most important peroxidase ensures the detoxification of peroxide and hydroperoxides to water and hydroxyl compounds, respectively (Pinto et al., 2003) so it play a protective role against oxidative stress (Van Der Oost et al., 1998; Van Der Oost et al., 2003).

Our results show a significant increase in GPx activity was found after both the first and second weeks in snails exposed to Weatfert fertilizer. These are in agreement with those of Farid et al. (2009) which reveal an increase of GPx in Lymnaea natalensis after treatment with niclosamide. Similar observations have been reported by El-Shennawy et al. (2012) who observed elevated GPx levels in snails exposed to cadmium, lead, copper 
and iron. This increase may be attributed to free radical production (Hermes et al., 2020) as shown by Orbea et al. (2000) and Radwan et al. (2010) on other snail species exposed to other pollutants. In contrast, a slight inhibition was observed in GPx activity with high phosphorus fertilizer treatment in Biomphalaria alexandrina snails (El-Deeb, 2017).

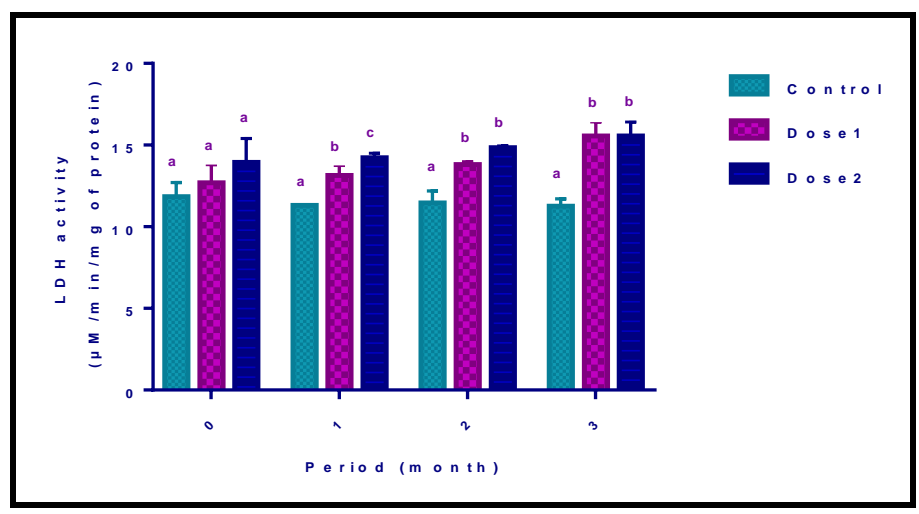

Figure 3. Effect of Weatfert on GPx activities ( $\mu M / m i n / m g$ of proteins) in the juvenile snails of $E$. vermiculata at different times during treatment (mean $\pm S E M, n=3$ ). The different lowercase letters indicate significant differences at the same time based on Tukey's HSD test $(p<0.05)$

Lactate dehydrogenase (LDH) is an enzyme found in nearly all living cells (animals, plants and prokaryotes). Lactate dehydrogenase converts pyruvate, the final product of glycolysis, to lactate when oxygen is absent or in short supply and it performs the reverse reaction during the Cori cycle in the liver. Our results are in accordance with Banaee et al. (2019) found that there was a significant increase in the activity of LDH in $G$. truncatula exposed to cadmium and dimethoate. A reduction was shown in LDH acitvity in B. alexandrina treated with atrazine and Roundup (Bakey et al., 2012). In the study of Banaee and Taheri (2019) a significant increase was observed in the activity of $\mathrm{LDH}$ in the G. truncatula exposed to sewage, which could be a physiological response to the stressful environmental. Increased LDH activity in the soft tissues of snails could be attributed to hypoxia and increased anaerobic glycolysis. This enzyme is involved in the metabolism of carbohydrates in cells and plays a key role in maintaining the balance between the catabolism and anabolism of carbohydrates in mollusks (Chen et al., 2011). In a stressful environment, LDH converts pyruvate into lactate, which in turn leads to the enhanced concentration of carboxylic acid (lactic acid) in tissues and hemolymph. Therefore, the $\mathrm{pH}$ of tissues and hemolymph decreases and causes specific physiological changes (Tunholi et al., 2017). In a study by Abdel-Halim et al. (2013), the LDH activity was observed to increase, which indicate a physiological response to the hypoxia-induced stress following the exposure of Helix aspersa to heavy metals. In addition, a significant increase has been reported in the LDH activity in the land snails ( $E$. vermiculata) exposed to methomyl (Khalil, 2016). A significant increase in the activity of LDH was observed in Deroceras reticulatum exposed to Caselio fertilizer (Abd-El Azeem and Sheir, 2018). LDH was chosen as a biomarker of the oxidative stress induced by the tested material (fertilizer, PMR). Increased oxidative stress biomarkers as lipid peroxidase in fertilizers polluted areas was documented by Yousef et al. (2017). Salama et al. (2005) recorded significant increase of the level of LDH in 
the land snail, Helix aspersa after exposure to several chemicals such as methomyl, carbofuran and chlorpyrifos. The increased release of LDH in mantle tissue is an indicative of cellular or membrane damage (Abd-El Azeem and Sheir, 2018).

\section{Effect on digestive gland structure}

Figure $4 A, B$ and $C$ represents the structure of digestive glands in control and treated snails after 3 months of exposition.

In control snails, the digestive gland epithelium presented a normal appearance at 0 day (Fig. 4A) and after 3 months (Fig. 4B) experimentation. The cells were readily distinguished, together with less abundant excretory and calcium cells.

In treated series, the examination of histological structure shows modifications. As shown in Figure $4 C$ and $D$, the epithelium of snails treated presented a significant hyperplasia of the gland, with the presence of fat cells. In addition, no necrosis and cell congestion were observed.


Figure 4. Transverse sections of digestive glands: in control snails ( $O$ day) $(A)$, in control snails (3 months) (B), in treated snails (D1) (3 months) $(C)$ and in treated snails (D2) (3 months) (D). Calcium Cell (CA); Digestive cell (DC); Excretory cell (EC); Excretory granules (eg); Fatty cell (FC); Tubular lumen (L) 
Beside the role of fertilizers in the growth of the plant it has a molluscidal effect. Sheir (2015) found that Caselio (plant fertilizer) caused tissue damage in the digestive tubules as necrosis, fusion and increased lipofuscin pigment in the freshwater snail, Lanistes carinatus. El-Deeb et al. (2015) exposed Biomphalaria alexandrina snails to the inorganic fertilizers (high phosphorus and high nitrogen content) and recorded histological alterations in the digestive glands. Triebskorn and Ebert (1989) studied the effect of carbamate and metaldehyde molluscicides on the digestive tract of Deroceras reticulatum. He described that mucus deficiency in the digestive tract due to metaldehyde exposure. Dummee et al. (2012) exposed the golden apple snail, Pomacea canaliculata to contaminated sediment with the metals ( $\mathrm{Fe}, \mathrm{Mn}, \mathrm{Cu}$ and $\mathrm{Zn}$ ) for two months. The results showed metals accumulation in the digestive tract and digestive gland higher than in the foot muscles. Some of pathological signs were cellular degeneration, necrosis, inflammatory responses and leaky intestine (gaps) (Abd-El Azeem and Sheir, 2018). Hamed et al. (2007) found a severe vacuolization in digestive cells of $E$. vermiculata treated with molluscicidal carbamates; methiocarb and methomyl. However, the histological examination of the hepatopancreas of the treated snails showed alterations as a response to all the treatments, and revealed the degeneration of the digestive tubules and the breakdown of the basement membrane in a dose-dependent manner, leading to a severe deterioration of the tissues in the concentration of $200 \mathrm{mg} / \mathrm{L}$ thiametoxam (Ait-Hamlet et al., 2012). Hepatocyte necrosis, kidney failure, kidney cell necrosis, muscular dystrophy and anemia, heart disease could causes by an increase in LDH in snails treated with a combination of Pirimicarb and lead acetate (Chen et al., 2011).

\section{Conclusion}

The data obtained show significant changes in the growth, biochemical parameters and enzymatic activity of the soft tissues of E. vermiculata snail's exposed to a fertilizer (Weafert). The fertilizer tested led to the depletion of energy reserves (lipid and carbohydrate levels) and an increase of proteins in the digestive gland of snails. An activation of the detoxification system was evidenced by an increase in the activity of GPx and LDH in the digestive gland. Lastly, structural alterations were observed in digestive gland from treated snails.

Acknowledgements. This work was supported by the National Fund for Scientific Research to Pr. N. Soltani (Laboratory of Applied Animal Biology) and the Ministry of High Education and Scientific Research of Algeria (PRFU Project D01N01UN120120180005 to Dr. S. Tine).

\section{REFERENCES}

[1] Abd-El Azeem, H. H., Sheir, S. K. (2018): Impacts of the plant fertilizer, Caselio on the slug, Deroceras reticulatum (Gastropoda, Stylommatophora): laboratory studies. Research Journal of Pharmaceutical, Biological and Chemical Sciences 9(1): 386-396.

[2] Abdel-Halim, K. Y., Abo El-Saad, A. M., Talha, M. M., Hussein, A. A., Bakry, N. M. (2013): Oxidative stress on land snail Helix aspersa as a sentinel organism for ecotoxicological effects of urban pollution with heavy metals. - Chemosphere 93(6): 1131-1138. 
[3] Abdel-Hamid, A. Z., Farrag E., Rizk, M., Omar, M., Mantawy, M. M. E. (1998): Effect of nitrogen, sulpher and phosphorus containing fertilizers and organophosphorus insecticide on reproduction of Biomphalaria alexandrina snails. - Egypt. J. Pharm. Sci. 38: 147-158.

[4] Afomezie, P. I., Ebenebe, C. I., Njoku, O. O., Ufele, A. N., Okonkwo, J. C. (2011): Effects of different soil treatments on weight gain, shell length and shell aperture of snails (Archachatina marginata). - Pak. J. Nutr. 10(2): 151-154.

[5] Aï Hamlet, S., Bensoltane, S., Djekoun, M., Yassi, F., Berrebbah, H. (2012): Histological changes and biochemical parameters in the hepatopancreas of terrestrial gastropod Helix aspersa as biomarkers of neonicotinoid insecticide exposure. - Afri. J. Biotech. 11(96): 16277-16283.

[6] Bakry, F. A., Hasheesh, W. S., Hamdi, S. A. H. (2011): Biological, biochemical, and molecular parameters of Hlisoma duryi snails exposed to pesticides malathion and deltamethrin. - Pestic. Biochem. Physiol. 101: 86-91.

[7] Bakry, F. A., Abdelsalam, H. A., Mahmoud, M. B., Hamdi, S. A. (2012): Influence of atrazine and roundup pesticides on biochemical and molecular aspects of Biomphalaria alexandrina snails. - Pestic. Biochem. Physiol. 104(1): 9-18.

[8] Bakry, F. A., El- Hommossany, K., Abd El-Atti, M. S., Ismail, S. M. (2013): Alterations in the fatty acid profile, antioxidant enzymes and protein pattern of Biomphalaria alexandrina snails exposed to the pesticides diazinon and profenofos. - Afric. J. Pharm. Pharmacol. 7: 2603-2612.

[9] Ballesteros, M. L., Wunderlin, D. A., Bistoni, M. A. (2009): Oxidative stress responses in different organs of Jenynsia multidentata exposed to endosulfan. - Ecotox. Environ. Safe. 72: 199-205.

[10] Banaee, M., Taheri, S. (2019): Metal bioaccumulation, oxidative stress, and biochemical alterations in the freshwater snail (Galba truncatula) exposed to municipal sewage. - J. Adv. Envir. Heal. Res. 7(1): 8-17.

[11] Banaee, M., Sureda, A., Taheri, S., Hedayatzadeh, F. (2019): Sub-lethal effects of dimethoate alone and in combination with cadmium on biochemical parameters in freshwater snail, Galba truncatula. - Comp. Biochem. Physiol. Part C: Toxicol \& Pharmacol. 220: 62-70.

[12] Bhattacharya, A., Sahu, S. K. (2016): Acute toxicity of NPK fertilizer on soil ecosystem using earthworm, Drawida willsi as a test specimen. Inter. - J. Adv. Pharm. Biol. Chem. 5(3): 233-238.

[13] Bhowmik, P. A., Banerjee, M. D., Mohasin, A. N. D., Somchoudhury, A. K. (2005): Effect of some herbicides on molluscs (Pila globosa Swainson) - an important nontarget fauna of low land crop ecosystem. - J. Crop. Weed. 2(1): 78-80.

[14] Bishop, J. M. (1983): Cellular oncogenes and retroviruses. - Ann. Rev. Biochem. 52: 301-354.

[15] Boyd, R. S. (2010): Heavy metal pollutants and chemical ecology: exploring new frontiers. - J. Chem. Ecol. 36: 46-58.

[16] Bradford, M. M. (1976): A rapid and sensitive method for the quantification of microgram quantities of protein utilizing the principle of protein-dye binding. - Analyt. Biochem. 72: 248-254.

[17] Chen, D. W., Su, J., Liu, X. L., Yan, D. M., Lin, Y., Jiang, W. M., Chen, X. H. (2011): Amino acid profiles of bivalve mollusks from Beibu Gulf, China. - J. Aquat. Food. Prod. Technol. 21(4): 369-379.

[18] Coeurdassier, M., Saint-Denis, M., Gomot-de Vaufleury, A., Ribera, D., Badot, P. M. (2001): The garden snail (Helix aspersa) as a bioindicator of organophosphorus exposure: effects of dimethoate on survival, growth, and acetylcholinesterase activity. - Environ. Toxicol. Chem. 20(9): 1951-1957. 
[19] De Silva, N. A. L., Marsden, I. D., Gaw, S., Glover, C. N. (2018): Acute waterborne cadmium toxicity in the estuarine pulmonate mud snail, Amphibola crenata. - Ecotox. Environ. Safe. 158: 274-283.

[20] Dittbrenner, N., Triebskorn, R., Moser, I., Capowiez, Y. (2010): Physiological and behavioural effects of imidacloprid on two ecologically relevant earthworm species (Lumbricus terrestris and Aporrectodea caliginosa). - Ecotoxicol. 19: 1567-1573.

[21] Douafer, L., Zaidi, N., Soltani, N. (2020): Seasonal variation of biomarker responses in Cantareus aspersus and physico-chemical properties of soils from Northeast Algeria. Environ. Sci. Pollut. Res. https://doi.org/10.1007/s11356-020-08694-4.

[22] Druart, C., Scheifler, R., de Vaufleury, A. (2010): Towards the development of an embryotoxicity bioassay with terrestrial snails: screening approach for cadmium and pesticides. - J. Hazard. Mater. 184(1-3): 26-33.

[23] Duchateau, G. H., Florkin, M. (1959): Sur la tréhalosémie des insectes et sa signification. - Arch. Physiol. Biochem. 67(2): 306-314.

[24] Dummee, V., Kruatrachue, M., Trinachart, W., Tanhan, P., Pokethitiyook, P., Damrongphol, P. (2012): Bioaccumulation of heavy metals in water, sediments, aquatic plant and histopathological effects on the golden apple snail in Beung Boraphet reservoir, Thailand. - Ecotoxicol. Environ. Safe. 86: 204-212.

[25] El-Deeb, F., Assem, M. M., Hasheesh, W., Tantawy A., EL-Sayed, S. (2015): Biological studies on the effect of certain inorganic fertilizers with observations on protein electrophoretic pattern of Biomphalaria alexandrina snails. - Adv. Environ. Biol. 9(21): 21-29.

[26] El-Deeb, F. A. A., Assem, M. M., Hasheesh, W., Hussein, R. M. A., Sayed, S. S. M. (2017): Biomarkers of oxidative stress in Biomphalaria alexandrina snails for assessing the effects of certain inorganic fertilisers. - Mollusc. Res. 37(4): 289-294.

[27] El-Shennawy, M. Z., Khalifa, E. Z., Ammar, M. M., Mousa, E. M., Hafez, S. L. (2012): Biological control of the disease complex on potato caused by root-knot nematode and Fusarium fungus. - Nematol. Mediter. 40: 169-172.

[28] Farid, N. M., Hamed, R. R., Shokeer, A. G. (2009): Glutathione and its related enzymes in fasciola snails (Lymnaea natalensis): purification and characterization of glutathione transferase. - Res. J. Agric. Biol. Sci. 5: 317-325.

[29] Flohe, L., Gunzler, W. A. (1984): Assays of glutathione peroxidase. - Methods of Enzymology 105: 114-121.

[30] Gabe, M. (1968): Détection des cations minéraux. - In: Gabe, M. (ed). Techniques histologiques. Masson et Cie, Paris.

[31] Gill, H. K., Garg, H. (1998): Pesticides: Environmental Impacts and Management Strategies. - In: Soloneski, S. (ed.) Pesticides-Toxic Aspects. InTech, London.

[32] Godan, D. (1983): Pest Slugs and Snails. - Springer-Verlag, Berlin.

[33] Goldsworthy, G. J., Mordue, W., Guthkelch, J. (1972): Studies on insect adipokinetic hormones. - Gener. Comp. Endocrinol. 18: 545-551.

[34] Gomot, A. (1994): Contribution à l'étude de la croissance d'escargots du genre Helix: influence de facteurs de l'environnement, nutrition et composition biochimique, contrôle neuroendocrine. - Doctorat Sciences de la Vie. n³98, Université de Besançon, France.

[35] Hamed, S. S., Abdelmeguied, N. E., Essawy, A. E., Radwan, M. A., Hegazy, A. E. (2007): Histological and ultrastructural changes induced by two carbamate molluscicides on the digestive gland of Eobania vermiculata. - J. Biol. Sci. 7: 1017-1037.

[36] Hermes-Lima, M. (2004): Oxygen in Biology and Biochemistry: Role of Free Radicals. In: Storey, K. B. (ed.) Functional Metabolism: Regulation and Adaptation. Wiley-Liss, Hoboken, pp. 319-368.

[37] Hill, B. R., Levi, C. (1954): Elevation of a serum component in neoplastic disease. Cancer. Res. 14(7): 513-515. 
[38] Ismail, N. M. M. (2009): Impact of certain chemical fertilizers on biological, biochemical parameters, protein patterns of Biomphalaria alexandrina snails and on their infection with Schistosoma mansoni. - J. Biol. Chem. Environ. Sci. 4: 499-528.

[39] ISO 15952. (2006): Effects of Pollutants on Juvenile Land Snails (Helicidae). Determination of the Effects on Growth by Soil Contamination. - International Organization for Standardization, Geneva.

[40] Kandil, M. A., El-Deeb, H. I., Mobarak, S. A., Eweis, E. A. (2009): Biochemical impacts of methomyl and abamectin and their binary mixtures with acetylsalicylic acid against the land snails Eobania vermiculata and Monacha obstructa. - Zeits fur die ges experim Med. 135: 545-561.

[41] Khalil, A. M. (2016): Impact of methomyl lannate on physiological parameters of the land snail Eobania vermiculata. - J. Bas. Appl. Zool. 74: 1-7.

[42] Lalthanzara, H., Ramanujam, S. N. (2010): Effect of fertilizer (NPK) on earthworm population in the agroforestry system of Mizoram, India. - Sci. Vision. 10(4): 159-167.

[43] McLoughlin, N., Yin, D., Maltby, L., Wood, R. M., Yu, H. (2000): Evaluation of sensitivity and specificity of two crustacean biochemical biomarkers. - Environ. Toxicol. Chem. 19: 2085-2092.

[44] Mohammadein, N. S., EL-Shenawy, N. S., AL-Fahmie, Z. H. H. (2013): Bioaccumulation and histopathological changes of the digestive gland of the land snail Eobania vermiculata (Mollusca: Gastropoda), as biomarkers of terrestrial heavy metal pollution in Taif city. - Ital. J. Zool. 80(3): 345-357.

[45] Moussard, C. (1999): La biochimie, Biochimie structurale et métabolique. Médecine, Pharmacie, Sciences. - De Boek \& Larciers, Bruxelles.

[46] Müller, O. F. (1774): Vermium terrestrium etfluviatilium, sen animalium infusoriorum, helminthicorum, et testaceorum, non marinorum, succincta historia. Vol. 2. Testacea. Heineck et Faber, Havnie et Lipsiae.

[47] Orbea, A., Fahimi, H. D., Cajaravill, M. P. (2000): Immunolocalization of four antioxidant enzymes in digestive glands of mollusks and crustaceans and fish liver. Histochem. Cell. Biol. 114: 393-404.

[48] Padmaja, R. J., Rao, M. B. (1994): Effect of an organochlorine and three organophosphate pesticides on glucose, glycogen, lipid and protein contents in tissues of the freshwater snail, Bellamya dissimilis (Muller). - Bull. Environ. Contam. Toxicol. 53: 142-148.

[49] Pinto, E., Sigaud-Kutner, T. C. S., Leitao, M. A. S., Okamoto, O. K., Morse, D., Colepicolo, P. (2003): Heavy metal-induced oxidative stress in algae. - J. Phycol. 39: 1008-1018.

[50] Porte, C., Van den Brink, N. W., Van der Oost, R. (2005): Biomarkers in Environmental Assessment. - In: Besten, P. J. den, Munawar, M. (eds.) Ecotoxicological Testing of Marine and Freshwater Ecosystems. CRC, Boca Raton, FL. DOI: 10.1201/9781420037500.ch3.

[51] Radwan, M. A., Essawy, A. E., Abdelmeguied, N. E., Hamed, S. S., Ahmed, A. E. (2008): Biochemical and histochemical on the digestive gland of Eobania vermiculata snails treated with carbamate pesticides. - Pestic. Biochem. Physiol. 90: 154-167.

[52] Radwan, M. A., El-Gendy, K. S., Gad, A. F. (2010): Biomarkers of oxidative stress in the land snail, Theba pisana for assessing ecotoxicological effects of urban metal pollution.Chemosphere 79: 40-46.

[53] Ragab, F. M. A., Shoukry, N. M. (2006): Influence of certain fertilizers on the activity of some molluscicides against Biomphalaria alexandrina and Lymnaea natalensis snails. J. Egypt. Soc. Parasitol. 36(3): 959-977.

[54] Rai, N., Ashiya, P., Rathore, D. S. (2014): Comparative study of the effect of chemical fertilizers and organic fertilizers on Eisenia foetida. - Inter. J. Innov. Res. Sci. Engin. Technol 3(5): 12991-98. 
[55] Regoli, F., Gorbi, S., Fattorini, D., Tedesco, S., Notti, A., Machella, N., Bocchett, R., Benedetti, M., Piva, F. (2006): Use of the land snail Helix aspersa as sentinel organism for monitoring ecotoxicologic effects of urban pollution: an integrated approach. Environ. Heal. Persp. 114(1): 63-69.

[56] Roh, J. Y., Park, Y. K., Park, K., Choi, J. (2010): Ecotoxicological investigation of $\mathrm{CeO}_{2}$ and $\mathrm{TiO}_{2}$ nanoparticles on the soil nematode Caenorhabditis elegans using gene expression, growth, fertility, and survival as endpoints. - Environ. Toxicol. Pharmacol. 29: $167-172$.

[57] Salama, A. K., Osman, K. A., Saber, N. A., Soliman, S. A. (2005): Oxidative stress induced by different pesticides in the land snail, Helix aspersa. - Pakist. J. Biol. Sci. 8: 92-96.

[58] Sallam, A., El-Wakeil, N. (2012): Biological and Ecological Studies on Land Snails and Their Control. - In: Soloneski, S. (ed.) Integrated Pest Management and Pest Control Current and Future Tactics. InTech Publishing, London.

[59] Schuytema, G. S., Nebeker, A. V., Griffis, W. L. (1994): Effects of dietary exposure to forest pesticides on the brown garden snail Helix aspersa Muller. - Arch. Environ. Contam. Toxicol. 26(1): 23-28.

[60] Sheir, S. K. (2015): The role of Caselio (plant fertilizer) exposure on digestive gland histology and heavy metals accumulation in the freshwater snail Lanistes carinatus. - J. Biosci. Appl. Res. 1(5): 223-233.

[61] Shibko, S., Koivistoinen, P., Tratyneek, C. A., Newhall, A. R., Freidman, L. (1966): A method for sequential quantitative separation and determination of protein, RNA, DNA, Lipid and Glycogen from a single rat liver homogenate or from a subcellular fraction. Analyt. Biochem. 19: 415-429.

[62] Sifi, K., Soltani, N. (2019): Seasonal changes of two biomarkers of oxidative stress (LDH, MDA) in the edible mollusc Donax trunculus (Mollusca: Bivalvia) from the Gulf of Annaba (Algeria): correlation with carbohydrate and lipid contents. - Molluscan J. 39(1): 44-52. https://doi.org/10.1080/13235818.2018.1499389.

[63] Snyman, R. G., Reinecke, A. J., Reinecke, S. A. (2005): Quantitative damages in the digestive gland cells of the snail Helix aspersa after exposure to the fungicide copper oxychloride. - Ecotoxicol. Environ. Safe. 60(1): 47-52.

[64] Triebskorn, R., Ebert, D. (1989): The Importance of the Mucus Production in Slugs' Reaction to Molluscicides on the Mucus Production System. - In: Henderson, I. F. (ed.) Slugs and Snails in World Agriculture. Monograph 41. British Crop Protection Council, London, pp. 373-378.

[65] Tunholi, V. M., Tunholi-Alves, V. M., Monteiro, C. O., da Silva, L. C., Dolinski, C. M., Castro, R. N. et al. (2017): Biological, biochemical and histological features of Bradybaena similaris (Gastropoda: Pulmonata) infected by Heterorabditis indica (Rhabditida: Heterorhabditidae) strain LPP1. - Exper. Parasitol. 179: 28-35.

[66] Ugokwe, C. U., Okafor, F. C., Okeke, P. C., Ezewudo, B. I., Olagunju, T. E. (2020): Induction of genetic alterations and oxidative stress in giant African land snail (Limicolaria aurora) exposed to municipal waste leachate. - Rev. Toxicol. 37: 19-25.

[67] Umminger, B. L. (1977): Relation of whole blood sugar concentrations in vertebrates to standard metabolic rate. - Compar. Biochem. Physiol. 56: 457-460.

[68] Van der Oost, R., Lopes, S. C. C., Komen, H., Satumalay, K., Van den Bos, R., Heida, H., Vermeulen, N. E. (1998): Assessment of environmental quality and inland water pollution using biomarker responses in caged carp (Cyprinus carpio): use of a bioactivation: detoxication ratio as biotransformation index (BTI). - Mar. Environ. Res. 46: 315-319.

[69] Van der Oost, R., Beyer, J., Vermeulen, N. P. (2003): Fish bioaccumulation and biomarkers in environmental risk assessment: a review. - Environ. Toxicol. Pharmacol. 13: 57-149. 
[70] Verlescar, X. N., Jena, K. B., Chainy, G. B. N. (2008): Seasonal variation of oxidative biomarkers in gills and digestive gland of green-lipped mussel, Perna viridis from Arabian Sea. - Estua. Coast. Shelf. Sci. 76: 745-752.

[71] WHO (1993): International Programme on Chemical Safety (IPCS). Biomarkers and Risk Assessment: Concepts and Principles. - Environ. Health. Criteria. 155, World Health Organization, Geneva.

[72] Yahyaabadi, M., Hamidian, A. H., Ashrafi, S. (2018): Dynamics of earthworm species at different depths of orchard soil receiving organic or chemical fertilizer amendments. Euras. J. Soil. Sci. 7(4): 318-325.

[73] Yousef, H. N. (2011): Physiological changes in the brown garden snail Eobania vermiculata induced by sublethal doses of two botanical molluscicides. - J. Egypt. German. Soc. Zool. 63: 375-397.

[74] Yousef, H. A., Abdelfattah, E. A., Augustyniak, M. (2017): Evaluation of Oxidative Stress Biomarkers in Aiolopus Thalassinus (Orthoptera: Acrididae) Collected from Areas Polluted by the Fertilizer Industry. - Ecotoxicol. 26(3): 340-350. 